\title{
Serum ferritin in juvenile chronic polyarthritis
}

\author{
A. W. CRAFT, E. J. EASTHAM, J. I. BELL, AND K. BRIGHAM
}

From the Departments of Child Health and Medicine, Royal Victoria Infirmary, Newcastle upon Tyne NE1 4LP

SUMMARY Six children with juvenile chronic polyarthritis were studied and their disease activity correlated with haematological values including serum ferritin. The latter is often raised above reference values, but even when within them appears to fluctuate significantly and correlates more closely with disease activity than any of the other parameters measured. We conclude that the serial measurement of serum ferritin may be a useful guide to the management of such children.

Moderate anaemia is often found in adult patients with rheumatoid arthritis and may be associated with a low serum iron concentration which is inversely related to the disease activity (Engskedt and Strandberg, 1966). Serial measurements have been suggested as a means of following the course of the disease (Whittingham et al., 1967). Changes in iron are thought to be characteristic (Turnbull, 1971) and, in spite of the low serum iron, total body iron is increased as evidenced by greater amounts of haemosiderin in the marrow, particularly in those with active disease (Hill and Greenbury, 1959). Furthermore, the amount of haemosiderin correlates well with the quantity of iron that can be chelated with desferrioxamine (Wardle and Israels, 1968). More recently the serum ferritin has been shown to be an accurate index of body iron stores in health (Walters et al., 1973), and Bentley and Williams (1974) have shown a close relationship with stainable bone marrow iron in adult rheumatoid patients, some of whom had raised serum ferritin levels. Similar changes in iron kinetics are thought to occur in children with juvenile chronic polyarthritis but these are not well documented. We have therefore studied a small group of children with this condition and correlated changes in iron and ferritin with alterations in disease activity.

\section{Patients and methods}

Six children, 4 male, 2 female, aged from 6 to 15 years who satisfied the criteria of Ansell and Bywaters (1959) for the diagnosis of juvenile chronic polyarthritis, were studied. All were Rose-Waaler

Accepted for publication July 15, 1976

Correspondence to Dr. A. W. Craft. Department of Child Health, Royal Victoria Infirmary, Newcastle upon Tyne NE1 4LP. negative and blood was taken at varying intervals during the course of the disease for estimation of haemoglobin, ESR (Westergren), serum iron, and sreum ferritin (immunoradiometric method of Addison et al., 1972). Clinical disease activity was assessed by the method of McConkey et al., (1972): an arbitary score of 100 was given at entry into the study and on each subsequent occasion was scored +10 if the patient was worse, 0 if unchanged, and -10 if improved from the previous visit. Assessment was a composite of the mother's, child's and doctor's (A.W.C.) opinion and was made before any laboratory findings were known. 4 of the children were receiving treatment with corticosteroids, D-penicillamine, and benorylate, and the other 2 with salicylates alone.

\section{Results}

Laboratory investigations at entry into the study are shown in Table 1. The references values for ferritin were obtained from 10 healthy children aged 2-16 years. The Fig. shows the course of one patient's clinical score and laboratory findings over a 7-month period, and the correlation between clinical rating and serum ferritin has been calculated (for each patient) using Spearman's Rank Correlation Coefficient for nonparametric measurements (Table 2). A similar correlation coefficient for the other parameters studied was calculated for individual patients and a mean of the separate coefficients calculated by $\mathrm{Z}$ transformation (Table 3 ).

Neither the negative correlation between serum iron and clinical rating/ferritin/ESR nor the positive correlation between ESR and clinical rating/ferritin was significant. The significance between ferritin and clinical rating at the $5 \%$ level would possibly be greater if more observations had been performed on Cases 5 and 6. 
Table 1 Mean values (+range) at entry into study

\begin{tabular}{lcl}
\hline & Study group & Normal \\
\hline Ferritin $(\mu \mathrm{g} / \mathrm{l})$ & $822(120-2000)$ & $35-155$ \\
Iron $(\mathrm{mmol} / \mathrm{l})$ & $3 \cdot 8(2 \cdot 7-5 \cdot 4)$ & $4 \cdot 8-27 \cdot 4$ \\
ESR $(\mathrm{mm} / \mathrm{h})$ & $68(38-104)$ & $1-15$ \\
Haemoglobin $(\mathrm{g} / \mathrm{dl})$ & $10 \cdot 5(8 \cdot 2-11 \cdot 8)$ & $11 \cdot 7-16 \cdot 2$ \\
\hline
\end{tabular}

Conversion: SI to traditional units-Iron: $1 \mathrm{mmol} / 1 \approx 5 \cdot 58 \mathrm{mg} / 100 \mathrm{ml}$.

Table 2 Ferritin vs. clinical rating

\begin{tabular}{llll}
\hline Case no. & $n$ & $t$ & $P$ \\
\hline 1 & 14 & 0.965 & $<0.001$ \\
2 & 14 & 0.936 & $<0.001$ \\
3 & 6 & 0.928 & $<0.05$ \\
4 & 5 & 1.000 & $<0.05$ \\
5 & 5 & 0.900 & NS \\
6 & 5 & 0.550 & NS \\
\hline
\end{tabular}

Table 3 Mean correlation coefficients

\begin{tabular}{lccl}
\hline & Clinical rating & & \\
Ferritin & $0.954^{*}$ & Ferritin & \\
Iron & -0.197 & -0.47 & Iron \\
ESR & 0.782 & 0.74 & -0.226 \\
\hline
\end{tabular}

*P<0.05.

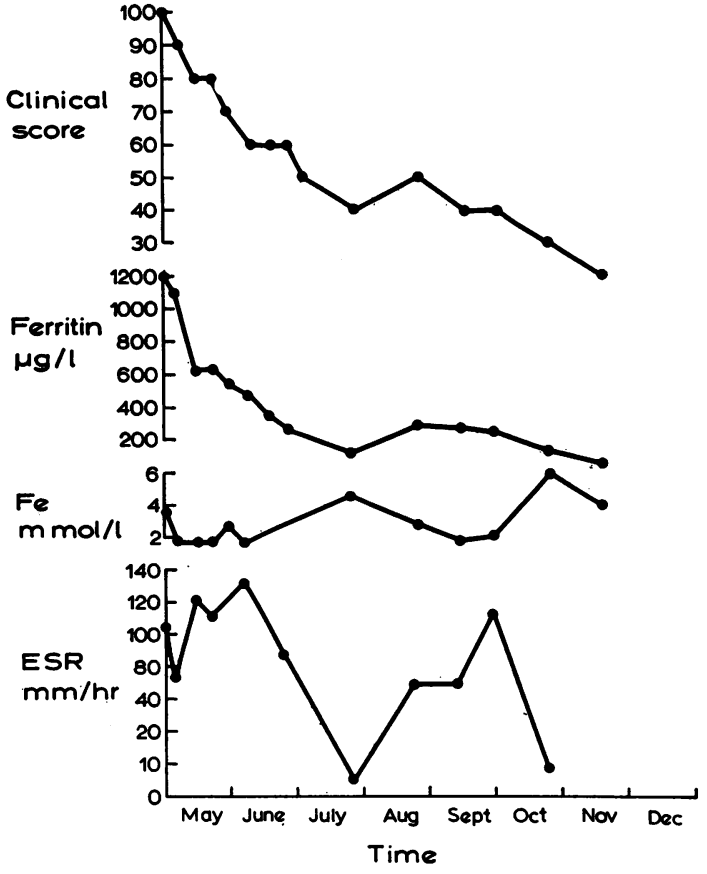

Fig. Clinical and laboratory course of one child.
Discussion

Our most difficult problem was to find a satisfactor measure of disease activity. Other methods have? been used in adult studies, for example, joint score

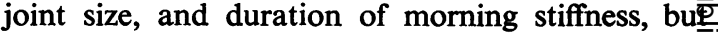
these are unsatisfactory and even less applicable t $\varnothing$ children. Lee et al (1974) have suggested that th patient's impression of his clinical state is the moses valuable indicator of the disease activity and although this is clearly influenced by many factors we have found the method used to be simple and satisfactory.

There was an overlap between our patients measurements and the reference values at entry int the study, and because of the wide variation io results we have concentrated on analysis of changes within individual patients as this will be the most useful clinically. Of the parameters studied, serun 9 ferritin appears to be the most useful, and even in one patient whose levels remained within the reference values throughout the study, a marke alteration occurred during the course of the disease. This is in contrast to healthy people in whom the serum ferritin does not alter during the day or from day to day (Siimes et al., 1974). However, raised levels of serum ferritin are found in many conditions e.g. haemolysis, liver disease, leukaemia, and dळ change within the course of some infective illnesses (E. J. Eastham, unpublished observations, 1976) $\stackrel{\mathbb{Q}}{\Omega}$ Interpretation should be guarded, therefore, but if our patients there was no evidence of these othes factors.

It is unlikely that the changes seen in serum ferritiक were due to the drug treatment, as corticosteroids do not have any effect on iron in health (Mowa $\overline{6}$ et al., 1969) and penicillamine has no significan effect on serum iron (Walshe and Patston, 1965) ot iron excretion (W. Lyle, personal communication 1976).

Our findings confirm that changes in iron kinetics similar to those in adults with rheumatoid arthritis occur in children with juvenile chronic polyarthritis: The marked increase of the reticuloendotheliain system in active disease creates a larger iron storage pool and it seems that in some way the iron is preferentially taken up by these cells and not madê available for normal haemopoiesis until the disease regresses. The serum ferritin is the most reliables laboratory reflection of disease activity that we havळ్ measured, and might be of value in those condition $\$$ where a more accurate assessment of clinicato activity is needed, e.g. drug trials, and would als $\vec{Q}$ serve as an indicator as to when iron replacemen $\$$ may benefit the haemoglobin status of the patient. 
We thank Drs. G. Dale and W. Walker for the haematological and biochemical investigations, and Sister H. Hope for ESR readings. E.J.E. is supported by a grant from the Scientific and Research Committee of the University Hospitals, Newcastle upon Tyne.

\section{References}

Addison, G. M., Beamish, M. R., Hales, C. N., Hodkins, M., Jacobs, A., and Llewellin, P. (1972). An immunoradiometric assay for ferritin in the serum of normal subjects and patients with iron deficiency and overload. Journal of Clinical Pathology, 25, 326-329.

Ansell, B. M., and Bywaters, E. G. L. (1959). Prognosis in Still's disease. Bulletin on Rheumatic Diseases, 9, 189-192.

Bentley, D. P., and Williams, P. (1974). Serum ferritin concentrations as an index of storage iron in rheumatoid arthritis. Journal of Clinical Pathology, 27, 786-788.

Engskedt, L., and Strandberg, D. (1966). Haematological data and clinical activity of the rheumatoid disease. Acta Medica Scandinavica, Suppl. 454, 13-29.

Hill, A. G. S., and Greenbury, C. L. (1959). Marrow iron in rheumatoid arthritis. Annals of the Rheumatic Diseases, 18, 57-58.

Lee, A. P., Webb, J., Anderson, J., and Buchanan, W. W. (1974). Technique for assessing the potential effectiveness of anti-rheumatic drugs. Annals of the Rheumatic Diseases, 33, 106-107.

McConkey, B., Crockson, R. A., and Crockson, A. P. (1972). The assessment of rheumatoid arthritis. Quarterly Journal of Medicine, 41, 115-125.

Mowat, A. G., Hothersall, T. E., and Aitchison, W. R. C (1969). Nature of anaemia in rheumatoid arthritis. XI. Changes in iron metabolism induced by the administration or corticotrophins. Annals of the Rheumatic Diseases, 28, 303-309.

Siimes, M. A., Addiego, J. E., and Daliman, P. R. (1974). Ferritin in serum: diagnosis of iron deficiency and iron overload in infants and children. Blood, 43, 581-590.

Turnbull, A. (1971). The blood in arthritis. Rheumatology and Physical Medicine, 9, 53-71.

Walshe, J. M., and Patston, V. (1965). Effect of penicillamine on serum iron. Archives of Disease in Childhood, 40 , 651-653.

Walters, G. O., Miller, F. M., and Worwood, M. (1973) Serum ferritin concentration and iron stores in normal subjects. Journal of Clinical Pathology, 26, 770-772.

Wardle, E. N., and Israels, M. C. G. (1968). The differential ferrioxamine test in rheumatoid disease, neoplastic and other haematological disorders. British Journal of Haematology, 14, 5-11.

Whittingham, S., Balazs, N. D. H., and Mackay, I. R. (1967) The effect of corticosteroid drugs on serum iron levels in systemic lupus erythematosus and rheumatoid arthritis. Medical Journal of Australia, 2, 639. 